\title{
Research council suggested as boost to Australian science
}

\section{Sydney}

AN Australian Research Council should be established as a channel for the federal government's direct support of basic research. This is the chief recommendation contained in a report from the Australian Science and Technology Council (ASTEC) on research in higher education, now before parliament. The council took 15 months to produce the report and considered 426 submissions.

The recommendations are intended to improve Australia's return on its investment by encouraging more research that will contribute directly to new products and processes as well as to improve the yield on that investment by persuading universities to specialize in areas where they have special expertise.

The report claims that supporting Australian tertiary institutions primarily for teaching rather than research has prevented the efficient use of research funds. Most funds for university research are now channelled through the Commonwealth Tertiary Education Commission (CTEC), but as part of the recurrent funds for university support, are not earmarked as such. The assumption is that university academics spend 30 per cent of their time on research and the rest teaching. Because staff numbers are based on the numbers of students, funds are spread evenly across all disciplines and, ASTEC says, Australian universities therefore end up as carbon copies of each other.

To ensure a greater concentration of research resources, ASTEC has called on CTEC to play a greater role in the distribution of funds within individual institutions, which have been asked to develop and publish their research strategies. In 1984, CTEC provided A $\$ 643$ million for research in universities, which is comparable with the level of support in most other countries of the Organization for Economic Cooperation and Development, but $\mathrm{A} \$ 339$ million of it corresponds to the salary equivalent of the time that academic staff spend on research, leaving just A $\$ 86$ million for salaries of technical and administrative support staff, equipment and expendable research materials.

On this basis, ASTEC concludes that specialization is the best way to produce significantly better results, even though this will mean that some academics will find themselves doing less research and more teaching. But university staff associations hold that every university academic has the right to do research and will bitterly oppose moves to create a subdivision of university staff who are allowed only to teach.

The Australian Research Council
(ARC) would be a statutory body answerable to the minister for science and would replace present schemes for direct research support, including the Australian Research Grants Scheme (ARGS) and the Commonwealth Program for the Promotion of Excellence in Research (see Nature 326, 5; 1987). Their combined budgets would provide the ARC with A $\$ 46$ million. ASTEC estimates that the ARC will need around $A \$ 96$ million a year. It recommends that it be given $\mathrm{A} \$ 66$ million in 1987-88 and built up to the full amount over the next four years. This would bring the ARC budget, as a fraction of gross national product and total higher education research spending, to a level comparable with research councils in other developed countries.

The study also recommends that the extra money should not be taken from CTEC's allocation. But in a hard economic climate where a 10 per cent increase (A $\$ 3$ million) in funds for the ARGS in the 1986 budget was hailed as a real victory for science, implementation of the last recommendation is unlikely.

Charles Morgan

\section{US-Soviet test-site monitoring a success \\ London}

ThE first stage of the joint Soviet-US experiment to monitor underground nuclear tests has ended successfully, a member of the US team, Professor Jonathan Berger of the University of California told Izvestiya last week.

The experiment, which is to run until July 1987, is sponsored jointly by the Soviet Academy of Sciences and the (nongovernment) US Natural Resources Research Council. The purpose of the experiment is to demonstrate that international verification of an underground test-ban treaty would be technically feasible, and that state-of-the-art seismic monitoring equipment is sufficiently accurate to eliminate erroneous readings from background noise or cavity effects.

The second stage of the experiment, Berger says, involves the siting of US monitoring equipment in $100-\mathrm{m}$ deep boreholes at a site near the Semipalatinsk testsite in Kazakhstan, which, Berger says, have already been drilled. A similar network of boreholes is also planned in Nevada and California, to monitor the US test-site. But although these monitoring stations are now almost ready, the Soviet team have not yet received clearance from Washington to visit them. Vera Rich

\section{EEC budget row threatening the research worker}

\section{London}

THE jobs of 3,000 European research workers engaged on collaborative research projects could be lost if the members of the European Economic Community (EEC) cannot agree on a research and development budget for the next five years. Last week the ministers failed, yet again, to agree the budget for the research programme, Framework, which was supposed to be effective on 1 January this year.

West Germany and Britain have been given until the end of this week to agree, although it remains unclear what sanctions will be imposed if they do not comply. Initially these two states, in partnership with France, challenged the proposed $£ 5,390$ million budget.

France relented but West Germany and the United Kingdom remain in opposition. Britain favours a ceiling of $£ 2,940$ million, says the Community must seek better value for money, use up 1,000 million ECU from the last budget and have a more professional approach to managing research projects.

The ministers have been trying to agree since last autumn when the EEC proposed its budget. By last week an unofficial compromise of $£ 4,600$ million was being discussed but still without success.

On his return from the European debate, Mr Geoffrey Pattie, Minister for Information Technology, scathingly criticized the EEC's management of information technology research, referring to it as a shambles. But the EEC remains determined that the new budget should be approved by all member states and has been given the backing of the European parliament.

The predictions of possible job losses came from members of the European Parliament (MEPs) who reject claims of member states that they can conduct effective national research and development programmes to compete against the might of Japan and the United States. And member states backing the new research programme maintain that the governments which oppose the Commission's proposals have never indicated which programmes they wish to cut back or cancel.

Three thousand researchers on information technology projects will have their contracts suspended "Because the adoption of the specific programmes is dependent on that of the general programme", claim the MEPs. "The whole confidence of the European scientific community would be shaken."

Bill Johnstone 